\title{
Ekspresi GLUT4 pada Neuron Hipokampus Rattus novergicus Diabetik yang Diinjeksi Streptozotocin dan Nicotinamide
}

\section{Expression of GLUT4 in Hippocampal Neurons of Streptozotocin and Nicotinamide-induced Diabetic Rattus novergicus}

\author{
Herpan Syafii $\mathrm{H}^{1}$, Novrita Padauleng ${ }^{2}$, Nurhidayati ${ }^{3}$, Ardiana Ekawanti ${ }^{4}$ \\ ${ }^{1}$ Laboratorium Neurologi Fakultas Kedokteran Universitas Mataram Mataram \\ ${ }^{2}$ Laboratorium Anatomi dan Histologi Fakultas Kedokteran Universitas Mataram Mataram \\ ${ }^{3}$ Laboratorium Farmakologi Fakultas Kedokteran Universitas Mataram Mataram \\ ${ }^{4}$ Laboratorium Biokimia Fakultas Kedokteran Universitas Mataram Mataram
}

\begin{abstract}
ABSTRAK
Diabetes melitus merupakan faktor risiko independen terjadinya gangguan kognisi. Upaya pengembangan hewan coba untuk penelitian pengaruh diabetes terhadap kognisi terus dilakukan. Rattus novergicus merupakan salah satu spesies tikus yang sering digunakan sebagai hewan model diabetik melalui injeksi streptozotocin. Protein GLUT4 neuron hipokampus diduga berperan penting dalam mempertahankan fungsi kognitif yang pada kondisi hiperglikemia. Penelitian ini bertujuan untuk menginvestigasi ekspresi GLUT4 pada neuron hipokampus Rattus novergicus diabetik yang diinjeksi streptozotocin dan nicotinamide. Penelitian eksperimental ini dilakukan dengan menggunakan 20 ekor Rattus novergicus yang dibagi secara acak menjadi 4 kelompok, yaitu 2 kelompok kontrol (K1 dan K2) dan 2 kelompok diabetik (D1 dan D2). Masing-masing kelompok terdiri dari 5 ekor tikus. Rattus norvegicus pada kelompok D1 dan D2 diinduksi diabetes dengan injeksi streptozotocin $70 \mathrm{mg} / \mathrm{kgBB}$ dan nicotinamide $110 \mathrm{mg} / \mathrm{kgBB}$ secara intraperitoneal dosis tunggal. Kadar glukosa darah puasa diperiksa pada hari ke-4 untuk memastikan tikus model diabetik mengalami hiperglikemia. Tikus kelompok K1 dan D1 diterminasi pada hari ke-7, sedangkan tikus kelompok K2 dan D2 diterminasi pada hari ke-14. Dilakukan pengambilan jaringan otak dan pemeriksaan imunohistokimia untuk melihat ekspresi GLUT4 pada neuron hipokampus. Hasil penelitian menunjukkan bahwa rerata ekpresi GLUT4 pada tikus kelompok diabetik secara signifikan lebih tinggi dibandingkan dengan tikus kelompok kontrol pada pengamatan hari ke-14 $(p<0,05)$, namun tidak pada pengamatan hari ke-7 ( $p>0,05)$. Rerata ekspresi GLUT4 tikus kelompok diabetik secara signifikan lebih tinggi pada pengamatan hari ke-14 dibandingkan dengan pengamatan hari ke-7 $(p<0,05)$. Dapat disimpulkan, terjadi peningkatan ekspresi GLUT4 pada neuron hipokampus Rattus novergicus diabetik yang diinjeksi streptozotocin dan nicotinamide.
\end{abstract}

Kata Kunci: Diabetes, GLUT4, nicotinamide, Rattus novergicus, streptozotocin

\begin{abstract}
Diabetes mellitus is an independent risk factor in the occurrence of cognitive disorders. Efforts to develop experimental animals for research on the effects of diabetes on cognition are still ongoing. Rattus novergicus is a rat species commonly used as a diabetic animal model through streptozotocin injection. GLUT4 protein hippocampal neurons are thought to play an important role in maintaining cognitive function under hyperglycemic condition. This study was aimed to investigate GLUT4 expression in hippocampal neurons of streptozotocin and nicotinamide-induced diabetic Rattus novergicus. This experimental study was conducted using 20 Rattus novergicus randomly divided into two control groups (K1 and K2) and two diabetic groups (D1 and D2). Each group consisted of 5 rats. Rattus norvegicus in D1 dan D2 was diabetic-induced by a single-dose injection of streptozotocin $70 \mathrm{mg} / \mathrm{kg}$ body weight and nicotinamide $110 \mathrm{mg} / \mathrm{kg}$ body weight intraperitoneally. Fasting blood glucose levels were examined on day 4 to ensure the diabetic rats had hyperglycemia. Rats in K1 and D1 were terminated on day-7, while rats in $K 2$ and D2 were terminated on day-14. Brain tissue extraction and immunohistochemical examination were performed to observe GLUT4 expression in hippocampal neurons. The results showed that the mean of GLUT4 expression in diabetic rats was significantly higher compared to control on day-14 $(p<0.05)$, but not on day-7 ( $p>0.05)$. The mean of GLUT4 expression in diabetic rats was significantly higher on day-14 compared to day-7 $(p<0.05)$. In short, GLUT4 expression is increasing in hippocampal neurons of diabetic Rattus novergicus induced with streptozotocin and nicotinamide.
\end{abstract}

Keywords: Diabetes, GLUT4, nicotinamide, Rattus novergicus, streptozotocin

Korespondensi: Herpan Syafii H. Laboratorium Neurologi Fakultas Kedokteran Universitas Mataram, Jl. Pendidikan no. 37 Mataram Nusa Tenggara Barat 83125 Tel. (0370)640874Email: herpanharahap@yahoo.co.id

DOI: http://dx.doi.org/10.21776/ub.jkb.2019.030.03.6 


\section{PENDAHULUAN}

Diabetes melitus merupakan salah satu faktor risiko independen untuk terjadinya gangguan fungsi kognitif (1). Pemahaman patofisiologi mengenai terjadinya gangguan kognitif terkait diabetes sangat penting untuk digunakan sebagai dasar pengembangan obat baru, misalnya golongan fitofarmaka, baik untuk mencegah maupun memperlambat perjalanan penyakit gangguan kognitif tersebut pada kondisi diabetes. Salah satu upaya yang paling memungkinkan untuk dilakukan dalam mencapai tujuan tersebut adalah dengan membuat suatu model hewan coba yang sesuai. Oleh karena itu, upaya pengembangan hewan coba model diabetik dan penentuan biomarker yang tepat untuk pengamatan respon populasi neuron yang berperan penting dalam mengemban fungsi kognitif terhadap kondisi diabetik, terutama populasi neuron di hipokampus, masih terus dilakukan $(2,3)$.

Saat ini terdapat beberapa cara pembuatan hewan model diabetik, diantaranya adalah induksi secara genetik, infeksi virus, induksi obese, dan induksi secara kimiawi. Pemilihan cara pembuatan hewan model tersebut secara umum tergantung dari penelitian yang akan dilakukan. Hewan model yang diinduksi secara genetik digunakan untuk menginvestigasi obat-obatan yang berperan dalam menurunkan stres oksidatif pada reticulum endoplasmik dari sel beta pankreas. Hewan model diabetik melalui infeksi virus digunakan untuk penelitian yang ditujukan untuk memahami peran virus dalam patogenesis diabetes melitus tipe 1. Hewan model yang diinduksi menjadi obese digunakan untuk menginvestigasi obat-obatan yang berperan dalam menurunkan resistensi insulin pada diabetes melitus tipe 2 . Hewan model diinduksi secara kimiawi digunakan untuk investigasi formulasi insulin yang baru dan untuk model transplantasi pankreas (4). Saat ini belum ada model hewan diabetik yang secara khusus dibuat untuk menginvestigasi pengaruh hiperglikemia pada kondisi diabetes terhadap perubahan fungsi kognitif.

Pembuatan hewan model diabetik melalui induksi kimiawi dapat dilakukan dengan 2 cara, yaitu melalui induksi dengan menggunakan alloxan dan streptozotocin (STZ). Aplikasi kedua metode tersebut secara umum praktis, relatif murah, dan tidak memerlukan biaya besar bila dibandingkan dengan beberapa metode lain yang telah dijelaskan sebelumnya. Keduanya menginduksi terjadinya diabetes pada hewan model dengan cara masuk kedalam sel beta pankreas melalui glucose transporter 2 (GLUT2) dan menimbulkan destruksi sel beta pankreas tersebut, sehingga menyebabkan terjadinya penurunan produksi insulin dan hiperglikemia (5). Diantara kedua cara tersebut, STZ merupakan cara terpilih dibandingkan dengan alloxon karena alloxan memiliki rentang dosis toksik yang lebih sempit dibandingkan STZ dan memiliki potensi kerusakan organ selain pankreas yang lebih besar, terutama organ ginjal (6). Induksi dengan STZ juga banyak digunakan dalam penelitian-penelitian investigasi pengaruh berbagai fitofarmaka terhadap fungsi kognitif pada kondisi diabetik (7-10).

Glucose transporter 4 (GLUT4) merupakan protein yang berperan penting dalam regulasi homeostasis glukosa di berbagai jaringan tubuh, terutama di jaringan otot, adipose, dan otak (11). Protein ini sensitif terhadap insulin, sehingga aktivitasnya diregulasi oleh insulin (12). Peran fisiologik GLUT4 di jaringan otak saat ini masih belum diketahui dengan pasti. Hal ini menarik perhatian banyak peneliti hingga muncul beberapa hipotesis mengenai peran fisiologik protein GLUT4 di jaringan otak tersebut, diantaranya adalah berperan penting dalam fungsi kognitif $(13,14)$. Penelitian ini bertujuan untuk menginvestigasi ekspresi GLUT4 pada populasi neuron hipokampus hewan coba yang diinduksi diabetes secara kimiawi dengan menggunakan STZ dan nicotinamide. Dalam penelitian ini menggunakan Rattus novergicus sebagai hewan model, merujuk pada penggunaan hewan model dari penelitian-penelitian sebelumnya yang sejenis $(15,16)$.

\section{METODE}

\section{Desain Penelitian}

Penelitian ini merupakan penelitian eksperimental laboratorium menggunakan 20 ekor hewan coba tikus Rattus novergicus yang diinduksi menjadi diabetes. Sampel dibagi menjadi empat kelompok, yaitu dua kelompok kontrol (kelompok hewan coba yang tidak induksi diabetes) dan dua kelompok diabetik (kelompok yang diinduksi diabetes). Pada dua kelompok kontrol, satu kelompok diterminasi pada hari ke-7 (Kelompok K1) dan satu kelompok lainnya diterminasi pada hari ke-14 (kelompok K2). Pada dua kelompok diabetik, satu kelompok diterminasi pada hari ke-7 (kelompok D1) dan kelompok hari ke-14 (kelompok D2). Induksi diabetes dilakukan secara kimiawi, yaitu dengan cara pemberian injeksi streptozotocin (STZ) $70 \mathrm{mg} / \mathrm{kgBB}$ dan nicotinamide $110 \mathrm{mg} / \mathrm{kgBB}$ dosis tunggal secara intraperitoneal. Pengambilan kadar glukosa darah puasa untuk kelompok diabetik dilakukan pada hari ke-7 dan ke-14 setelah dipuasakan selama 8 jam. Ekspresi GLUT4 neuron hipokampus dari keempat kelompok hewan coba dinilai dengan menggunakan metode imunohistokimia.

\section{Model Hewan Coba}

Model hewan coba yang digunakan adalah tikus Rattus novergicus strain wistar jantan berusia 2-3 bulan, berat badan 200-300gram, dengan keadaan sehat tanpa cacat fisik. Tikus ditempatkan didalam kandang berukuran $50 \times 60 \mathrm{~cm}$, tiap kandang berisi 5 ekor tikus. Tikus diadaptasikan selama 7 hari dan diberikan makan dan minum standar setiap hari. Penelitian ini telah mendapatkan persetujuan etik dari Komisi Etik Penelitian Kesehatan Universitas Mataram dengan nomor 258/UN18.8/ETIK/2018.

\section{Induksi Diabetes}

Sepuluh ekor tikus Rattus novergicus dari kelompok diabetik yang terbagi menjadi kelompok D1 dan D2 diinjeksi nicotinamide $110 \mathrm{mg} / \mathrm{kgBB}$ dosis tunggal secara intraperitoneal. Dilakukan injeksi streptozotocin $70 \mathrm{mg} / \mathrm{kgBB}$ secara intraperitoneal dosis tunggal pada kedua kelompok tersebut, 15 menit setelah pemberian injeksi nicotinamide. Kondisi hiperglikemik akan dicapai 72 jam setelah induksi, yang dikonfirmasi dengan pemeriksaan kadar glukosa darah puasa dengan menggunakan glucometer. Pemeriksaan induksi diabetes dikerjakan di Laboratorium Terpadu Fakultas Kedokteran Universitas Mataram.

\section{Persiapan Sampel Darah Hewan Coba}

Dilakukan pengambilan darah puasa secara intrakardiak setelah tikus dipuasakan selama 8 jam pada hari terminasi ke-7 (kelompok D1) dan hari ke-14 (kelompok D2). Darah 
ditampung dalam tabung EDTA untuk disentrifus dan diambil serumnya. Dilakukan pemeriksaan kadar glukosa darah puasa dari sampel serum yang diperoleh dengan menggunakan alat glucometer. Pemeriksaan kadar glukosa darah puasa dikerjakan di Laboratorium Hepatika Mataram.

\section{Persiapan Sampel Otak Hewan Coba}

Dilakukan terminasi hewan coba dengan menggunakan ether dosis letal pada hari ke-7 (kelompok K1 dan D1) dan hari ke-14 (kelompok K2 dan D2). Jaringan otak tikus segera diambil dengan cara membuka tulang kranium. Jaringan otak tersebut difiksasi dalam larutan PBS formalin $10 \%$. Proses pengirisan jaringan hipokampus dan pembuatan sediaan untuk pemeriksaan imunohistokimia GLUT4 dikerjakan di Pemeriksaan imunohistokimia GLUT4 hipokampus dikerjakan di Laboratorium Patologi Anatomi Fakultas Kedokteran Universitas Gadjah Mada.

\section{Imunohistokimia}

Irisan sampel hipokampus yang telah dipersiapkan untuk pemeriksaan ekspresi GLUT4 ditetesi dengan xylol I, xylol II, etanol $100 \%$, etanol $95 \%$, etanol $90 \%$, etanol $80 \%$, etanol $70 \%$, dan larutan akuades. Irisan disimpan dalam inkubator $37^{\circ} \mathrm{C}$ selama 3 hari, kemudian disimpan dirak penyimpanan hingga digunakan saat pewarnaan imunositokimia. Dilakukan proses blocking endogenous peroksidase menggunakan $\mathrm{H} 2 \mathrm{O} 2$ 0,3\%, antigen retrieval dengan teknik HIER (Heat Induced Epitope Retrieval) menggunakan buffer TRIS EDTA pH 9,0 pada suhu sedang selama 20 menit, dan dicuci dengan larutan PBS pH 7,4. Irisan diberikan background sniper selama 10 menit untuk mencegah ikatan dengan protein non-spesifik dan diinkubasikan dengan antibodi primer anti-GLUT4 (antibodi poliklonal, abcam ab33780) selama semalam pada suhu $4^{\circ} \mathrm{C}$. Dilakukan inkubasi dengan antibodi sekunder (trekki universal link) selama 10 menit, dilakukan pencucian menggunakan PBS pH 7,4 selama 5 menit sebanyak 3 kali. Pada tahap akhir irisan ditetesi Streptavidin peroksidase (Trek Avidin HRP label) diberikan selama 10 menit, kemudian dilakukan pencucian ulang menggunakan PBS pH 7,4. Visualisasi digunakan betazoid DAB 1:100 selama 5 menit tanpa cahaya, dicuci dengan akuades. Pemeriksaan imunohistokimia GLUT4 hipokampus dikerjakan di Laboratorium Patologi Anatomi Fakultas Kedokteran Universitas Gadjah Mada.

\section{Analisis Data}

Analisis data dikerjakan dengan menggunakan program SPSS versi 22 dengan uji beda Mann-Whitney, uji korelasi Pearson, uji korelasi Spearman, uji Wilcoxon, dan uji $t$ berpasangan. Hasil statistik bermakna jika nilai $p<0,05$.

\section{HASIL}

\section{EkspresiGLUT4}

Uji Mann-Whitney untuk rerata ekspresi GLUT4 antara kelompok K1 dan D1 pada pengamatan hari ke-7 tidak menunjukkan adanya perbedaan yang bermakna $(p=0,730)$, sedangkan uji Mann-Whitney untuk rerata ekspresi GLUT4 antara kelompok K2 dan D2 pada pengamatan hari ke-14 menunjukkan adanya perbedaan yang bermakna $(p=0,032)$ (Gambar $1 A)$. Uji Wilcoxon untuk rerata ekspresi GLUT4 pada kelompok diabetik antara pengamatan hari ke-7 (D1) dan hari ke-14 (D2) menunjukkan adanya perbedaan yang bermakna $(p=0,012)$ (Gambar 1B).
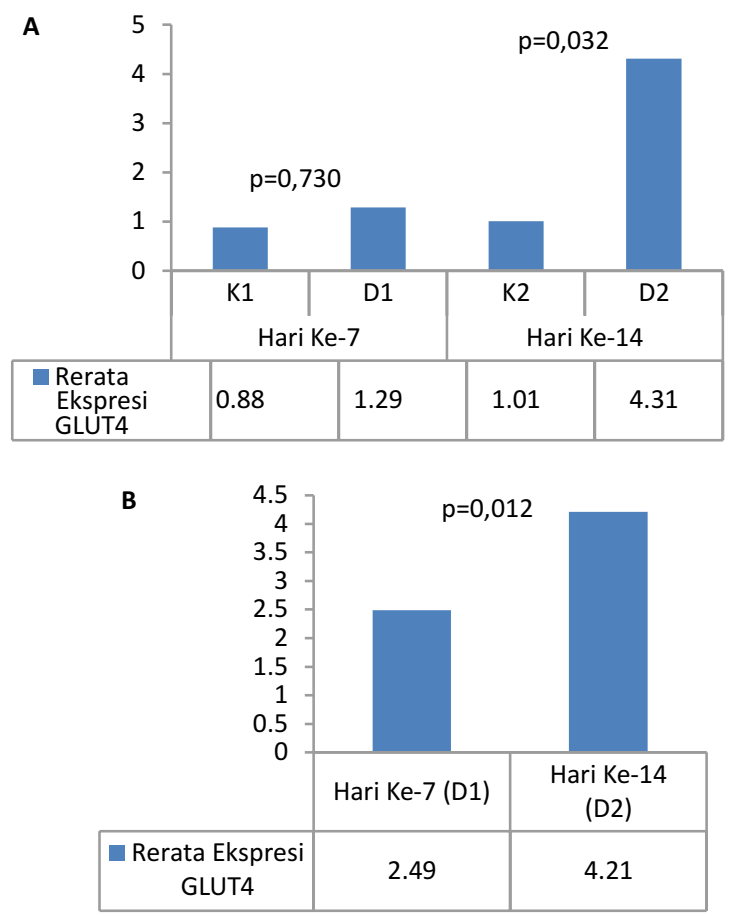

Gambar 1. Ekspresi GLUT4 neuron hipokampus pada kelompok kontrol dan diabetik pada pengamatan hari ke-7 (K1 dan D1) dan hari ke-14 (K2 dan D2)

Keterangan:

A. Grafik perbedaan rerata ekspresi GLUT4 antara kelompok kontrol dan diabetik pada pengamatan hari ke-7 dan 14

B. Grafik perbedaan rerata ekspresi GLUT4 kelompok diabetik pada pengamatan hari ke-7 dan 14 .
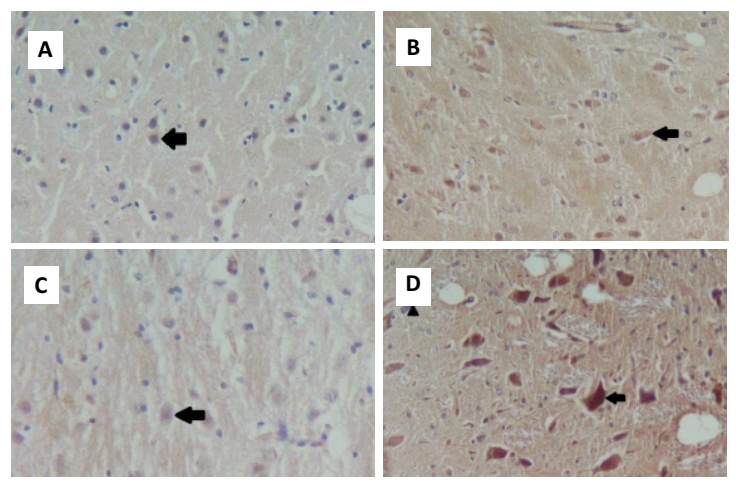

\section{Gambar 2. Hasil pemeriksaan imunohistokimia GLUT4 antar} kelompok

Keterangan:

A. Pemeriksaan imunohistokimia ekspresi GLUT4 kelompok K1

B. Pemeriksaan imunohistokimia ekspresi GLUT4 kelompok D1

C. Pemeriksaan imunohistokimia ekspresi GLUT4 kelompok K2

D. Pemeriksaan imunohistokimia ekspresi GLUT4 kelompok D2

(Tanda panah menunjukkan sel yang positif mengekspresikan GLUT4 pada pemeriksaan imunohistokimia yang ditandai dengan sitoplasma yang terwarnai coklat, anak panah menunjukkan sel imunonegatif GLUT4 yang ditandai dengan sitoplasma yang terwarnai biru).

Pemeriksaan imunohistokimia mengkonfirmasi hasil uji beda rerata ekspresi GLUT4 antara kelompok K1 dan D1 pada pengamatan hari ke-7 (Gambar 21A dan B) dan antara kelompok K2 dan D2 pada pengamatan hari ke-14 (Gambar 2C dan D). Hasil tersebut menunjukkan bahwa ekspresi GLUT4 neuron hipokampus dari tikus Rattus novergicus yang diinduksi diabetes mengalami 
peningkatan yang signifikan pada pengamatan hari ke-14 pasca induksi diabetes.

Kadar Glukosa Darah Puasa Hewan Coba Diabetik dan Korelasinya dengan Ekspresi GLUT4

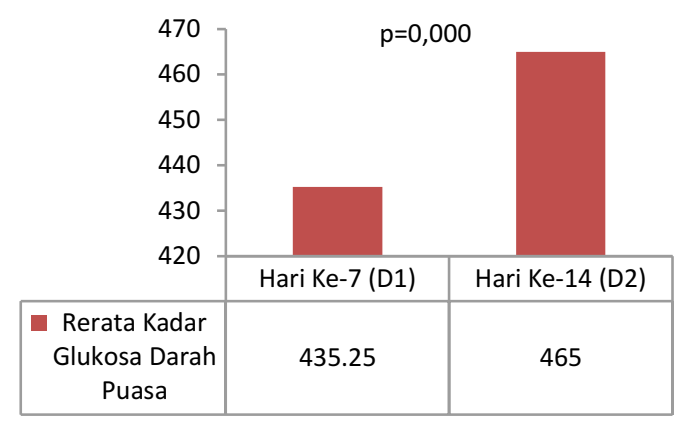

Gambar 3. Kadar glukosa darah puasa kelompok diabetik pada pemeriksaan hari ke-7 (D1) dan hari ke-14 (D2).

Uji t berpasangan untuk rerata kadar glukosa darah puasa tikus kelompok diabetik antara hari ke-7 dan 14 menunjukkan perbedaan yang bermakna $(p=0,000)$ (gambar 2). Uji korelasi Pearson untuk rerata kadar glukosa darah puasa dan ekspresi GLUT neuron hipokampus tikus kelompok diabetik pada pengamatan hari ke-7 tidak menunjukkan adanya korelasi antara keduanya $(p=0,155)$, begitu juga dengan uji korelasi Spearman yang digunakan untuk keduanya pada pengamatan hari ke-14 $(p=0,200)$. Hasil tersebut menunjukkan bahwa tikus Rattus novergicus tetap konsisten menunjukkan hiperglikemia sampai dengan pengamatan hari ke-14, namun kondisi hiperglikemia tersebut tidak berkorelasi dengan ekspresi GLUT4 neuron hipokampus.

\section{DISKUSI}

Diabetes melitus diketahui sebagai salah satu faktor risiko vaskuler terjadinya gangguan fungsi kognitif, mulai dari derajat ringan (mild cognitive impairment) hingga berat (vascular dementia). Penelitian-penelitian yang ditujukan untuk memahami patogenesis terjadinya gangguan kognitif terkait diabetes pada hewan coba masih terus dilakukan, termasuk diantaranya adalah penelitian dalam hal pembuatan hewan model diabetik yang sesuai dan penentuan biomarker yang diekspresikan oleh struktur otak yang berperan membentuk fungsi kognitif yang perubahannya dipengaruhi oleh penyakit diabetes melitus $(4,17,18)$. Diantara berbagai teknik induksi diabetik pada hewan coba, induksi secara kimiawi dengan menggunakan injeksi STZ dosis tunggal merupakan metode yang paling banyak digunakan. Keunggulan dari teknik induksi diabetik ini dibandingkan dengan metodemetode lainnya adalah sederhana, bisa menyebabkan kerusakan secara selektif pada pankreas, dan menyebabkan kondisi hiperglikemia secara cepat, yaitu sejak hari kedua pasca injeksi $(4,19)$. Hal tersebut didukung oleh hasil penelitian ini, yaitu pada pengamatan hari ke-7, tikus kelompok diabetik sudah mengalami hiperglikemia dan kondisi tersebut secara bermakna bertambah berat pada pengamatan hari ke-14. Dengan demikian, hewan model diabetik pada penelitian ini merupakan hewan model yang sesuai dan dapat digunakan untuk penelitian lanjutan, diantaranya adalah penelitian evaluasi dampak hiperglikemia terhadap bagian otak yang penting fungsi kognitif, misalnya hipokampus. Pemberian nicotinamide pada penelitian ini bertujuan untuk melindungi sebagian sel beta pankreas dari kerusakan total akibat injeksi STZ melalui mekanisme antioksidan (19).

Dengan adanya fakta bahwa GLUT4 diekspresikan di hipokampus, suatu struktur penting untuk proses konsolidasi memori, dan ekspresi protein tersebut ditingkatkan oleh insulin pada kondisi hiperglikemia, maka protein ini sangat mungkin berperan penting dalam menjaga fungsi kognitif pada kondisi diabetes melitus. Penelitian ini merupakan penelitian eksperimental yang ditujukan untuk menilai ekspresi GLUT4 pada neuron hipokampus pada tikus model diabetes melitus dalam kondisi hiperglikemia. Hasil penelitian ini menunjukkan bahwa ekspresi GLUT4 neuron hipokampus pada kelompok diabetik meningkat secara signifikan pada pengamatan minggu ke-14, namun tidak pada minggu ke-7 dibandingkan dengan kelompok kontrol (Gambar 1A-F). Pada waktu pengamatan yang sama, seperti yang telah dijelaskan sebelumnya, baik pada hari ke-7 maupun 14, tikus kelompok diabetik masih menunjukkan kondisi hiperglikemia. Mengingat GLUT4 hanya bisa diaktivasi oleh insulin yang dihasilkan oleh sel beta pankreas (11), maka temuan tersebut kemungkinan disebabkan karena terjadinya regenerasi secara parsial dari sel beta pankreas, baik karena masih ada sel beta yang masih bertahan hidup pasca injeksi STZ dan mendapatkan fungsinya kembali maupun terdapat sel beta yang baru yang berasal dari pertumbuhan sel prekursornya (20), atau melalui efek protektif dari nicotinamid terhadap sebagian sel beta pankreas (19), sehingga dihasilkan insulin yang mampu meningkatkan ekspresi GLUT4, namun belum cukup untuk menurunkan kadar glukosa darah puasa secara bermakna. Suatu penelitian menunjukkan bahwa proses regenerasi sel beta pankreas pada tikus model diabetik dapat terjadi mulai hari ke-10 perlakuan (4). Perlu dilakukan penelitian serupa yang disertai dengan pemeriksaan kadar insulin serum dan pemeriksaan histopatologi jaringan pankreas pada pengamatan hari ke-7 dan 14, agar dapat ditarik kesimpulan apakah pada kedua hari pengamatan tersebut, terutama hari ke-14, telah terjadi proses regenerasi pankreas dan telah terjadi produksi insulin yang memiliki korelasi yang bermakna dengan peningkatan ekspresi GLUT4 tersebut.

Dapat disimpulkan bahwa ekspresi GLUT4 neuron hipokampus Rattus novergicus yang diinduksi diabetik dengan teknik injeksi STZ dan nicotinamide mengalami peningkatan pada hari ke-14. Peningkatan tersebut tidak berkorelasi dengan kondisi hiperglikemia, kemungkinan disebabkan karena proses regenerasi sel beta pankreas secara parsial. Perlu dilakukan penelitian lanjutan dengan pemeriksaan kadar insulin serum dan histopatologi jaringan pankreas untuk mengkonfirmasi kemungkinan tersebut.

\section{DAFTAR PUSTAKA}

1. Harahap HS, Indrayana $Y$, dan Lestari R. Hubungan Tingkat Risiko Obstructive Sleep Apnea dan

Sindroma Metabolik dengan Fungsi Kognitif Global. Jurnal Kedokteran Brawijaya. 2018; 30(2): 133-137.

2. Wu J, Zhou SL, Pi LH, et al. High Glucose Induces 
Formation of Tau Hyperphosphorylation via Cav-1mTOR Pathway: A Potential Molecular Mechanism for Diabetes-Induced Cognitive Dysfunction. Oncotarget. 2017; 8(25): 40843-40856.

3. Pei B and Sun J. Pinocembrin Alleviates Cognition Deficits by Inhibiting Inflammation in Diabetik Mice. Journal of Neuroimmunology. 2018; 314: 42-49.

4. King AJF. The Use of Animal Models in Diabetes Reseach. British Journal of Pharmacology. 2012; 166(3): 877-894.

5. Al-awar A, Kupai K, Veszelka M, et al. Experimental Diabetes Mellitus in Different Animal Model. Journal of Diabetes Research. 2016; 2016: 1-12.

6. Tripathi $\mathrm{V}$ and Verma J. Different Models Used to Induce Diabetes: A Comprehensive Review. International Journal of Pharmacy and Pharmaceutical Sciences. 2014; 6(6): 29-32.

7. Georgy GS, Nassar NN, Mansour HA, and Abdallah DM. Cerebrolysin Ameloriates Cognitive Deficits in Type III Diabetik Rats. PloS One. 2013; 8(6): e64847.

8. Liu X, Liu M, Mo Y, et al. Naringin Ameliorates Cognitive Deficits in Streptozotocin- induced Diabetik Rats. Iranian Journal of Basic Medical Sciences. 2016; 19(4): 417-422.

9. Darwatik D, Ratnawati R, Rianawati SB, and Sarwono I. Pengaruh Antosianin Ubi Ungu terhadap TNF- $\alpha$, Apoptosis dan Memori Spasial Hipokampus Tikus Model Diabetes Melitus. Jurnal Kedokteran Brawijaya. 2017; 30(1): 12-18.

10. Barriere DA, Noll C, Roussy G, et al. Combination of High-Fat/Highfructose Diet and Low-Dose Streptozotocin to Model Long-Term Type-2 Diabetes Complications. Scientific Reports. 2018; 8(1): 1-16.

11. Shah K, DeSilva S, and Abbruscato T. The Role of Glucose Transporters in Brain Disease: Diabetes and Alzheimer's Disease. International Journal of
Molecular Science. 2012; 13(10): 12629-12655.

12. Olson AL. Regulation of GLUT4 and Insulin-Dependent Glucose Flux. International Scholarly Research Network Molecular Biology. 2012; 2012: 1-12.

13. Matioli MNPS and Nitrini R. Mechanisms Linking Brain Insulin Resistance to Alzheimer's Disease. Dementia and Neuropsychologia. 2015; 9(2): 96-102.

14. Pearson-Leary J and McNay EC. Novel Roles for the Insulin Regulated Glucose Transporter-4 in Hippocampally Dependent Memory. The Journal of Neuroscience. 2016; 36(47): 11851-11864.

15. Abdel-Rehemi ES, Abd-Elmoneim A, and Hosni AA. Fatty-Sucrosed Diet/Minimal Dose of StreptozotocinTreated Rat: A Novel Model of Gestational Diabetes Mellitus, Metabolic and Inflammatory Insight. Journal of Diabetes and Metabolism. 2014; 5(9): 1-8.

16. Balbaa M, Abdulmalek SA, and Khalil S. Oxidative Stress and Expression of Insulin Signaling Proteins in the Brain of Diabetik Rats: Role of Nigella Sativa Oil and Antidiabetik Drugs. PloS One. 2017; 12(5): e0172429.

17. Sadi G and Konat D. Resveratrol Regulates Oxidative Biomarkers and Antioxidant Enzymes in the Brain of Streptozotocin-induced Diabetik Rats. Pharmaceutical Biology. 2016; 54(7): 1156-1163.

18. Mehta BK and Banerjee S. Characterization of Cognitive Impairment in Type 2 Diabetik Rats. Indian Journal of Pharmaceutical Sciences. 2017; 79(5): 785-793.

19. Kishore L, Kajal A, and Kaur N. Role of Nicotinamide in Streptozotocin Induced Diabetes in Animal Models. Journal of Endocrinology and Thyroid Research. 2017; 2(1): 1-4.

20. Grossman EJ, Lee DD, Tao J, et al. Glycemic Control Promotes Pancreatic Beta-Cell Regeneration in Streptozotocin - Induced Diabetik Mice. Plos One. 2010; 5(1): e8749. 